BuletinIlmiah Mat. Stat. danTerapannya (Bimaster)

Volume 08, No. 4 (2019), hal 759-764.

\title{
METODE ANALISIS KORESPONDENSI BERGANDA \\ UNTUK MENGIDENTIFIKASI KARAKTERISTIK MAHASISWA BIDIKMISI FMIPA UNTAN
}

\author{
Wirdha Eryani, Dadan Kusnandar, Hendra Perdana
}

\begin{abstract}
INTISARI
Analisis korespondensi berganda merupakan teknik deskriptif yang diterapkan pada variabel yang berskala ordinal dan nominal. Metode ini dapat menganalisis kedekatan antara variabel dependen dan variabel independen secara eksploratif. Penelitian ini menggunakan metode analisis korespondensi berganda untuk mengidentifikasi karakteristik mahasiswa bidikmisi FMIPA Untan. Hasil penelitian adalah karakteristik mahasiswa penerima beasiswa bidikmisi dikelompokkan menjadi tiga yaitu, kelompok pertama mahasiswa dengan IPK rendah, kelompok kedua mahasiswa dengan IPK sedang dan kelompok ketiga adalah mahasiswa dengan IPK tinggi. Karakteristik kelompok pertama adalah asal daerah mahasiswa luar Kota Pontianak, penghasilan orang tua perbulan antara Rp1.000.000 sampai dengan Rp1.500.000, pekerjaan ayah petani/nelayan/buruh tani, status keberadaan ayah ada, pendidikan terakhir ibu (Tidak Sekolah/SD/SMP) dan pendidikan terakhir ayah (Tidak Sekolah/SD/SMP). Karakteristik kelompok kedua adalah penghasilan orangtua perbulan kurang dari Rp1.000.000, jenis kelamin mahasiswa laki-laki, status asal sekolah SLTA Negeri, pekerjaan ibu wiraswata/petani, status keberadaan ibu ada, jenis kelamin mahasiswa perempuan, status asal sekolah SLTA Swasta dan asal daerah mahasiswa luar Kota Pontianak. Sedangkan karakteristik kelompok ketiga adalah asal daerah mahasiswa Kota Pontianak, pendidikan terakhir ibu SMA, pekerjaan ayah pegawai swasta, pendidikan terakhir ayah SMA dan pekerjaan ayah buruh non tani.
\end{abstract}

Kata Kunci: Korespondensi Berganda, Bidikmisi, Kategorik

\section{PENDAHULUAN}

Bidikmisi adalah beasiswa berupa bantuan pendidikan yang diberikan pemerintah Republik Indonesia melalui Direktorat Jenderal Pendidikan Tinggi, Kementrian Riset, Teknologi dan Pendidikan Tinggi. Beasiswa ini diberikan untuk mahasiswa yang tidak mampu secara ekonomi akan tetapi memiliki potensi akademik yang baik, untuk menempuh pendidikan di perguruan tinggi sampai dapat lulus tepat waktu [1]. Mahasiswa penerima beasiswa bidikmisi diharuskan memenuhi syarat IPK minimal yang telah ditetapkan yaitu 3,00. Mahasiswa yang tidak memenuhi syarat IPK minimal akan diberikan surat peringatan. Setelah diberi surat peringatan sebanyak tiga kali, maka akan dipertimbangkan kelanjutan penerimaan beasiswa bidikmisi ini. Dilihat dari hal tersebut, banyak mahasiswa bidikmisi yang terpaksa diberhentikan karena tidak mencapai syarat IPK minimal. Salah satu upaya yang dapat dilakukan adalah mengidentifikasi karakteristik mahasiswa penerima beasiswa bidikmisi berdasarkan prestasi akademik. Identifikasi karakteristik dapat dilakukan dengan menggunakan metode analisis korespondensi berganda.

Analisis korespondensi merupakan teknik deskriptif yang diterapkan pada variabel yang berskala ordinal dan nominal [2]. Analisis korespondensi merupakan salah satu teknik statistika yang digunakan untuk mengetahui hubungan antar variabel dependen dan variabel independen. Kelebihan analisis korespondensi adalah dengan penyajian data secara grafis dapat menyingkat data sehingga mudah diinterpretasikan karena dapat menyederhanakan aspek data dengan menyajikan data secara visual [3]. Penelitian ini menggunakan metode analisis korespondensi berganda untuk mengidentifikasi karakteristik mahasiswa bidikmisi FMIPA Untan angkatan 2014 dan 2015.

Perhitungan metode korespondensi berganda diawali dengan membentuk matriks indikator. Setelah matriks indikator terbentuk, selanjutnya menghitung matriks korespondensi. Lalu hitung nilai massa kolom dan massa baris. Selanjutnya adalah penguraian nilai singular. Penguraian nilai singular adalah 
bagian terpenting pada analisis korespondensi berganda. Penguraian nilai singular berhubungan untuk menghitung nilai eigen, nilai singular dan untuk menentukan koordinat profil kolom. Nilai koordinat profil kolom akan digunakan untuk menggambarkan plot korespondensi berganda pada peta persepsi.

Data yang digunakan dalam penelitian ini adalah data sekunder yang diperoleh dari kantor comdev dan outreaching Untan berupa data mahasiswa penerima beasiswa bidikmisi FMIPA Untan angkatan 2014 dan 2015. Ukuran data yang digunakan adalah sebanyak 226 sampel dan terdiri dari 11 variabel. Data tersebut diolah dengan software Microsoft Excel dan $R$.

\section{PETA PERSEPSI}

Peta persepsi adalah sebuah bentuk representasi visual dari gambaran persepsi responden terhadap beberapa objek yang terdiri dari dua atau lebih dimensi. Setiap objek tersebut akan memiliki posisi spasial pada peta yang telah dideskripsikan sesuai kesamaan (similarity) dan preferensi (preference) ke objek lainnya. Pembentukan peta persepsi tersebut bertujuan untuk melihat hubungan antar variabel yang digunakan. Variabel yang memiliki kesamaan akan saling berdekatan, sedangkan yang memiliki banyak perbedaan akan saling berjauhan [4].

\section{ANALISIS KORESPONDENSI BERGANDA}

Analisis korespondensi berganda merupakan perluasan dari analisis korespondensi untuk kasus lebih dari dua variabel kategori. Analisis korespondensi berganda adalah metode visualisasi data yang digunakan untuk mengetahui hubungan dan pola antara beberapa variabel yang bersifat kategorik [5]. Analisis korespondensi berganda digunakan untuk menentukan karakteristik penciri dari kelompok yang terbentuk. Karakteristik tersebut dapat dilihat dari kedekatan antara variabel dependen dan variabel independen dalam plot korespondensi berganda.

\section{TAHAPAN PENGERJAAN ANALISIS KORESPONDENSI BERGANDA}

Tahapan pada Metode Korespondensi Berganda sebagai berikut:

1. Membentuk matriks indikator

Matriks indikator pada analisis korespondensi berganda dilambangkan dengan $\boldsymbol{Z}$. Banyaknya variabel yang digunakan dinotasikan sebagai $q$. Matriks indikator merupakan matriks berukuran $n \times p$ dengan $n$ merupakan banyaknya observasi dan $p$ adalah banyaknya kategori untuk seluruh variabel kategorik yang digunakan.

$$
\boldsymbol{Z}_{i}=\left[\begin{array}{llll}
z_{11} & z_{12} & \cdots & z_{1 p} \\
z_{21} & z_{22} & \cdots & z_{2 p} \\
\vdots & \vdots & \ddots & \vdots \\
z_{n 1} & z_{n 2} & \cdots & z_{n p}
\end{array}\right]
$$

2. Menghitung matriks korespondensi

Matriks korespondensi merupakan matriks yang elemen-elemennya merupakan elemen-elemen dari tabel kontingensi yang dibagi dengan $n$. $n$ merupakan jumlah sampel dan $q$ merupakan banyaknya variabel yang digunakan.

$$
\boldsymbol{P}=\frac{\boldsymbol{Z}}{n \times q}
$$

3. Menghitung massa kolom matriks indikator

Massa kolom menyatakan proporsi suatu kategori terhadap semua kategori yang ada. Massa kolom matriks indikator dilambangkan dengan $\boldsymbol{c}_{i}$ dimana $n$ merupakan jumlah sampel, $q$ 
merupakan banyaknya variabel yang digunakan, $\boldsymbol{Z}_{i}^{T}$ adalah matriks indikator transpose variabel ke $i$ dan 1 adalah matriks 1 .

$$
\boldsymbol{c}_{i}=\frac{1}{n \times q} \boldsymbol{Z}_{i}^{T} 1
$$

4. Menghitung massa baris matriks indikator

Massa baris pada analisis korespondensi berganda merupakan proporsi dari setiap sampel terhadap keseluruhan sampel. Massa baris matriks indikator dilambangkan dengan $\boldsymbol{r}_{i}$ dimana $n$ merupakan jumlah sampel, $q$ merupakan banyaknya variabel yang digunakan, $\boldsymbol{Z}_{i}$ adalah matriks indikator variabel ke $i$ dan 1 adalah matriks 1 .

$$
\boldsymbol{r}_{i}=\frac{1}{n \times q} \boldsymbol{Z}_{i} 1
$$

5. Penguraian nilai singular

Bagian terpenting pada analisis korespondensi berganda adalah penguraian nilai singular. Langkah yang dilakukan adalah:

a) Menentukan matriks standar residual standar yaitu:

$$
\begin{aligned}
& \lambda_{1}^{z} \geq \lambda_{2}^{z} \geq \cdots \geq \lambda_{q}^{z}>0 \\
& \boldsymbol{H}=D_{r}^{-\frac{1}{2}}\left(P-r c^{T}\right) D_{c}^{-\frac{1}{2}}
\end{aligned}
$$

dengan $D_{r}=\operatorname{diag}(r)$ dan $D_{c}=\operatorname{diag}(c)$. Elemen dari matriks $\boldsymbol{H}$ adalah:

$$
h_{i j}=\frac{\left(p_{i j}-r_{i} c_{j}\right)}{\sqrt{r_{i} c_{j}}}
$$

b) Menentukan nilai singular dekomposisi dari $\boldsymbol{H}$ yaitu:

$$
H=U D_{\lambda} V^{T} \quad \text { dengan } \quad V^{T} V=I
$$

6. Nilai eigen dan nilai singular

Nilai eigen atau inersia utama pada analisis korespondensi berganda menggunakan inersia utama matriks indikator $\left(\lambda_{i}^{z}\right)$. Nilai $\lambda_{i}^{z}$ merupakan nilai eigen singular value decomposition (SVD). $D_{\lambda}$ dengan $\lambda_{1}^{z} \geq \lambda_{2}^{z} \geq \cdots \geq \lambda_{q}^{z}>0$ dimana $q$ adalah banyaknya variabel. Nilai singular adalah akar dari inersia utama matriks indikator, yaitu $D_{\lambda}^{\frac{1}{2}}$. Nilai singular digunakan untuk menentukan koordinat profil kolom.

7. Koordinat profil kolom

Koordinat profil pada analisis korespondensi berganda dibedakan menjadi dua, yaitu koordinat profil kolom dan koordinat profil baris. Koordinat profil kolom digunakan untuk menggambarkan plot kategori-kategori, sedangkan koordinat profil baris digunakan untuk menggambarkan plot antar sampel. Tujuan utama dari analisis korespondensi berganda adalah untuk mengetahui gambaran antar kategori, maka pada analisis ini koordinat profil baris tidak digunakan untuk menggambarkan plot pada peta persepsi. Sebelum memperoleh koordinat utama profil kolom, terlebih dahulu dihitung koordinat standar profil kolom yang dirumuskan:

$$
L=V D_{c}^{-\frac{1}{2}}
$$

Dan koordinat utama profil kolom dirumuskan sebagai: 


$$
F=L D_{\lambda}
$$

\section{STUDI KASUS}

Data penelitian yang digunakan adalah data sekunder yang diperoleh dari kantor comdev dan outreaching Untan yaitu data mahasiswa penerima beasiswa bidikmisi FMIPA Untan angkatan 2014 dan 2015. Sampel yang digunakan pada penelitian ini sebanyak 226 sampel dengan 11 variabel yang terdiri dari 10 variabel independen dan 1 variabel dependen.

Analisis data pada penelitian ini menggunakan metode Korespondensi Berganda. Analisis data dilakukan dengan bantuan software $R$. Variabel-variabel yang digunakan pada penelitian ini adalah sebagai berikut:
1. IPK semester $5(Y)$
7. Pekerjaan ayah $\left(\mathrm{X}_{6}\right)$
2. Jenis kelamin $\left(X_{1}\right)$
8. Pekerjaan ibu $\left(X_{7}\right)$
3. Status SMA $\left(X_{2}\right)$
9. Pendidikan ayah $\left(X_{8}\right)$
4. Asal Daerah $\left(X_{3}\right)$
10. Pendidikan ibu $\left(X_{9}\right)$
5. Status keberadaan ayah $\left(X_{4}\right)$
11. Penghasilan orangtua per bulan $\left(X_{10}\right)$
6. Status keberadaan ibu $\left(X_{5}\right)$

\section{STATISTIK DESKRIPTIF}

Statistik deskriptif dilakukan untuk mendapatkan beberapa informasi dari data. Melalui statistik deskriptif dapat diketahui frekuensi dan persentase data.

\begin{tabular}{|c|c|c|c|}
\hline Variabel & Kategori & Frekuensi & Persentase \\
\hline \multirow[t]{3}{*}{ IPK Semester 5} & 1. $\quad$ IPK $<3,00$ & 62 & $26,5 \%$ \\
\hline & 2. IPK $3,00 \leq \mathrm{IPK} \leq 3,50$ & 128 & $57,1 \%$ \\
\hline & 3. $\mathrm{IPK}>3,50$ & 36 & $16,4 \%$ \\
\hline \multirow[t]{2}{*}{ Jenis kelamin } & 1. Laki-laki & 79 & $35 \%$ \\
\hline & 2. Perempuan & 147 & $65 \%$ \\
\hline \multirow[t]{2}{*}{ Status SMA } & 1. SLTA Negeri & 173 & $76,5 \%$ \\
\hline & 2. SLTA Swasta & 53 & $23,5 \%$ \\
\hline \multirow[t]{3}{*}{ Asal daerah } & 1. Kota Pontianak & 48 & $21,2 \%$ \\
\hline & 2. Luar Kota Pontianak & 174 & $77 \%$ \\
\hline & 3. Luar Kalimantan Barat & 4 & $1,8 \%$ \\
\hline \multirow[t]{2}{*}{ Status keberadaan ayah } & 1. Ada & 205 & $90,7 \%$ \\
\hline & 2. Almarhum & 21 & $9,3 \%$ \\
\hline \multirow[t]{2}{*}{ Status keberadaan ibu } & 1. Ada & 224 & $99,1 \%$ \\
\hline & 2. Almarhum & 2 & $0,9 \%$ \\
\hline \multirow[t]{5}{*}{ Pekerjaan ayah } & 1. Buruh Non Tani & 29 & $12,8 \%$ \\
\hline & $\begin{array}{l}\text { 2. Petani/Nelayan/Buruh } \\
\text { Tani }\end{array}$ & 109 & $48,2 \%$ \\
\hline & 3. Wiraswasta/Pedagang & 23 & $10,2 \%$ \\
\hline & 4. Tidak Bekerja & 19 & $8,4 \%$ \\
\hline & 5. Pegawai Swasta & 46 & $20,4 \%$ \\
\hline \multirow[t]{2}{*}{ Pekerjaan ibu } & 1. IRT & 104 & $46 \%$ \\
\hline & 2. Wiraswasta/Petani & 122 & $54 \%$ \\
\hline \multirow[t]{3}{*}{ Pendidikan ayah } & 1. Tidak Sekolah/SD/SMP & 127 & $56,2 \%$ \\
\hline & 2. SMA & 93 & $41,2 \%$ \\
\hline & 3. Perguruan Tinggi & 6 & $2,7 \%$ \\
\hline
\end{tabular}


2. SMA

3. Perguruan Tinggi

Statistik Deskriptif

\begin{tabular}{cllrr}
\hline Variabel & \multicolumn{1}{c}{ Kategori } & Frekuensi & Persentase \\
\hline Penghasilan Orangtua perbulan & 1. $<1.000 .000$ & 107 & $47,3 \%$ \\
& 2. $1.000 .000 \leq \mathrm{X}<1.500 .000$ & 78 & $37,5 \%$ \\
& 3. $1.500 .000 \leq \mathrm{X}<2.000 .000$ & 30 & $13,3 \%$ \\
& 4. $2.000 .000 \leq \mathrm{X} \leq 3.000 .000$ & 11 & $4,9 \%$ \\
\hline
\end{tabular}

Nilai rata-rata IPK mahasiswa penerima beasiswa bidikmisi adalah sebesar 3,02. IPK terendah yang diperoleh mahasiswa bidikmisi adalah sebesar 1,4 dan IPK tertinggi sebesar 3,93. Mahasiswa bidikmisi didominasi oleh mahasiswa yang berjenis kelamin perempuan. Status SMA mahasiswa bidikmisi rata-rata berasal dari SLTA Negeri. Asal daerah mahasiswa bidikmisi paling banyak adalah mahasiswa yang berasal dari luar Kota Pontianak. Status keberadaan ayah dan ibu mahasiswa bidikmisi paling banyak, adalah orang tua nya masih ada. Untuk pekerjaan ayah mahasiswa bidikmisi, yang terbanyak adalah ayah mahasiswa yang bekerja sebagai petani/nelayan/buruh tani. Sedangkan untuk pekerjaan ibu mahasiswa bidikmisi, yang terbanyak adalah ibu mahasiswa yang bekerja sebagai wiraswasta/petani. Untuk pendidikan ayah dan pendidikan ibu mahasiswa bidikmisi, yang terbanyak adalah mahasiswa yang pendidikan terakhir ayah dan ibunya Tidak Sekolah/SD/SMP. Variabel terakhir adalah variabel penghasilan orang tua perbulan. Kondisi ekonomi mahasiswa penerima beasiswa bidikmisi dapat dilihat berdasarkan penghasilan orang tua perbulan. Penghasilan orang tua mahasiswa yang terbanyak adalah kurang dari Rp1.000.000. Persyaratan penerima beasiswa bidikmisi yang dikeluarkan oleh Direktorat pendidikan Tinggi (DIKTI) untuk penghasilan orang tua perbulannya adalah kurang dari Rp3.000.000. Hal ini menunjukkan bahwa seleksi penerimaan yang dilakukan Untan dari segi ekonomi mahasiswa sudah cukup sesuai dengan persyaratan yang ditentukan oleh Dikti.

\section{ANALISIS KORESPONDENSI BERGANDA}

Pada Gambar 1 karakteristik untuk setiap kategori IPK dapat diidentifikasi berdasarkan plot-plot yang berdekatan dengan kategori IPK. Berdasarkan kontribusi yang diberikan variabel IPK, dimensi yang dapat membedakan karakteristik kategori variabel IPK adalah dimensi 1 dan dimensi 2. Kategori IPK berdasarkan dimensi 1 dan dimensi 2 dibedakan menjadi tiga yaitu kategori IPK rendah, kategori IPK sedang dan kategori IPK tinggi. Warna pada plot korespondensi berganda digunakan untuk membedakan kategori yang ada. Untuk variabel dengan kategori A ditandai warna hitam, variabel dengan kategori B ditandai warna merah, variabel dengan kategori $\mathrm{C}$ ditandai warna hijau, variabel dengan kategori $\mathrm{D}$ ditandai warna biru tua dan variabel dengan kategori $\mathrm{E}$ ditandai warna biru tosca.

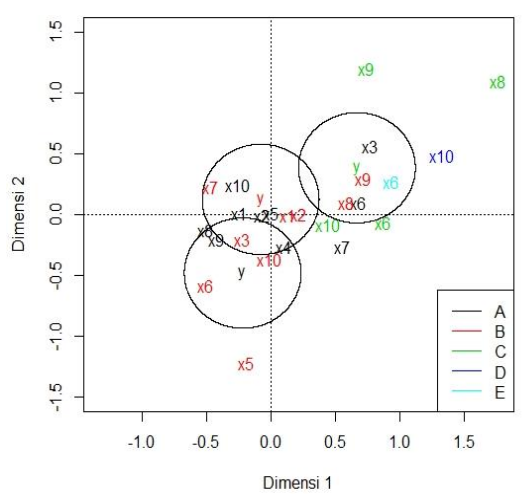

Gambar 1 Plot Korespondensi Berganda 
Kategori IPK rendah (y_A) memiliki karakteristik pekerjaan ayah petani/nelayan/buruh tani (x6_B), penghasilan orang tua perbulan antara Rp1.000.000 sampai Rp1.500.000 (x10_B), asal daerah mahasiswa adalah luar Kota Pontianak (x3_B), status keberadaan ayah ada (x4_A), pendidikan ibu (Tidak Sekolah/SD/SMP) (x9_A) dan pendidikan ayah (Tidak Sekolah/SD/SMP) (x8_A).

Kategori IPK sedang (y_B) memiliki karakteristik penghasilan orang tua perbulan kurang dari Rp1.000.000 (x10_A), jenis kelamin laki-laki (x1_A), status asal sekolah SLTA Negeri (x2_A), pekerjaan ibu wiraswasta/petani (x7_B), status keberadaan ibu ada (x5_A), jenis kelamin perempuan (x1_B), status asal sekolah SLTA Swasta (x2_B) dan asal daerah mahasiswa adalah luar Kota Pontianak (x3_B).

Kategori IPK tinggi (y_C) memiliki karakteristik mahasiswa berasal dari Kota Pontianak (x3_A), pendidikan ibu SMA (x9_B), pekerjaan ayah pegawai swasta (x6_E), pendidikan ayah SMA (x8_B) dan pekerjaan ayah buruh non tani (x6_A).

\section{KESIMPULAN}

Karakteristik mahasiswa penerima beasiswa bidikmisi berdasarkan analisis korespondensi berganda dikelompokkan menjadi tiga yaitu, kelompok pertama mahasiswa dengan IPK rendah, kelompok kedua mahasiswa dengan IPK sedang dan kelompok ketiga adalah mahasiswa dengan IPK tinggi. Kelompok pertama adalah mahasiswa kategori IPK rendah yang memiliki karakteristik asal daerah mahasiswa luar Kota Pontianak, penghasilan orang tua perbulan antara Rp1.000.000 sampai dengan Rp1.500.000, pekerjaan ayah petani/nelayan/buruh tani, status keberadaan ayah ada, pendidikan terakhir ibu (Tidak Sekolah/SD/SMP) dan pendidikan terakhir ayah (Tidak Sekolah/SD/SMP). Kelompok kedua adalah mahasiswa kategori IPK sedang yang memiliki karakteristik penghasilan orang tua perbulan kurang dari Rp1.000.000, jenis kelamin mahasiswa lakilaki, status asal sekolah SLTA Negeri, pekerjaan ibu wiraswasta/petani, status keberadaan ibu ada, jenis kelamin mahasiswa perempuan, status asal sekolah SLTA Swasta dan asal daerah mahasiswa luar Kota Pontianak. Sedangkan kelompok ketiga adalah kategori mahasiswa IPK tinggi yang memiliki karakteristik asal daerah mahasiswa adalah Kota Pontianak, pendidikan terakhir ibu SMA, pekerjaan ayah pegawai swasta, pendidikan terakhir ayah SMA dan pekerjaan ayah buruh non tani.

\section{DAFTAR PUSTAKA}

[1]. Pedoman Bidikmisi; 2012.

[2]. Mattjik A., Sumertajaya I. Sidik Peubah Ganda dengan Menggunakan SAS, Bogor: IPB Press; 2011.

[3]. Lesnussa Y, Kelian H, Persulessy E, Djami R., Talakua M. Aplikasi Analisis Korespondensi Berganda terhadap Pemetaan Perkembangan Pembangunan Kota Ambon, Ambon: Universitas Pattimura Ambon; 2017.

[4]. Greenacre M. Weight Metric Multidimensional Scaling. Barcelona: Universitas Pompeu Fabra; 2003.

[5]. Greenacre M., Blasius J. Multiple Correspondence Analysis and Related Methods. New York: Chapman dan Hall/CRC; 2006.

WIRDHA ERYANI : Jurusan Matematika FMIPA UNTAN, Pontianak eryaniw@gmail.com

DADAN KUSNANDAR : Jurusan Matematika FMIPA UNTAN, Pontianak dkusnand@untan.ac.id

HENDRA PERDANA : Jurusan Matematika FMIPA UNTAN, Pontianak hendra.perdana@math.untan.ac.id 